\title{
MARKETING ASPECTS OF DEVELOPING TOURISM SERVICES MARKET IN UKRAINE \& THE BALTIC COUNTRIES
}

\author{
Ganna Gorina', Valentina Barabanova ${ }^{2}$
}

\begin{abstract}
Under the conditions of modern European integration processes, the quality of providing tourism services, which should meet the requirements of the population as much as possible, gains momentum. The regulation of tourism development in Ukraine according to European standards and regulations impose the task of upgrading the tourism industry, search for innovative instruments to improve its functioning based on the best European practices example of the Baltic States. Marketing approaches in managing the demand for tourism services by means of innovative technologies are insufficiently defined. Among the scholars who investigated the marketing aspects in the field of tourism activities should be distinguished the following: N. E. Kudla, I. Yu. Martynov, O. M. Pravyk, I. M. Shkoda and so on. The methodology is based on a systematic approach to the market for tourist services, marketing analysis as a management concept for this market, on the use of modelling as a methodological principle and a method of scientific knowledge. The mechanisms of increasing the efficiency of marketing activities in the field of tourism through the structural-functional model and model of management of the marketed approach system are determined. At the present stage, the issues of finding and implementing modern mechanisms for the formation and management of demand for a tourism product remain unsolved. Results. The article is aimed at developing innovative methods for managing the process of implementing marketing approaches to the market for tourist services in Ukraine. Priority is the development of mechanisms for the formation of demand for tourism products through marking technologies. The authors developed a system of marking approaches, which includes the factors of the effectiveness of travel services; marking methods and techniques; forms of realization of tourist services. The mechanism of formation and management of demand for a tourist product, as well as communicative and social methods of increasing the efficiency of marking activity in the tourist services market in Ukraine, is determined. Practical implications. The article considers mechanisms of increasing the efficiency of marketing activities in the field of tourism. The expediency of using the European experience of the Baltic States for the development of tourism in Ukraine is emphasized. Directions of further researches are offered. The structural-functional model of the system of marketing approaches and the organizational model of operational management of the process of realization of marketing approaches to the market for tourist services are developed. Value/originality. The use of the proposed models will more effectively increase the efficiency of marketing activities in the modern market for tourist services. The authors prove that modelling, development, and implementation of models of marketing approaches is a powerful mechanism for achieving a new quality of tourism services market and Ukraine.
\end{abstract}

Key words: European integration, tourism of Baltic countries, system approach, market for tourism services, structural-functional model, marketing technologies, marketing communications.

JEL Classification: M31, D47, L84

\section{Introduction}

Structural changes in the economy, instability of the environment require a revision of the forms and methods of managing the market of tourism services. The topical issue is to define new and improving existing marketing tools, mechanisms for shaping the demand of consumers for tourism services by means of marketing communications. The search and development of new marketing approaches, the abandonment of obsolete authoritarian methods of managing the work of tourist enterprises, the introduction of innovative marketing technologies actualize the possibilities of realizing

\footnotetext{
Corresponding author:

${ }^{1}$ Donetsk National University of Economics and Trade named after Mykhailo Tugan-Baranovsky, Ukraine.

E-mail: gorina@donnuet.edu.ua

ORCID: https://orcid.org/0000-0003-0900-0640

${ }^{2}$ Donetsk National University of Economics and Trade named after Mykhailo Tugan-Baranovsky, Ukraine.

E-mail: barabanova@donnuet.edu.ua

ORCID: https://orcid.org/0000-0002-2954-4090
} 
and satisfying the consumers' demand for qualitative tourism services.

Implementation of marketing approaches to the market for tourism services requires taking into account social and psychological factors promoting the tourist product. It is time for the development of mechanisms for their influence on the formation and management of demand for tourism services.

The problems of tourism with elements of the system approach are covered in the works: A. Alexandrova, I. Berezhny, M. Kabeshkin, O. Lyubivtseva, K. Cooper, and others. Among the scholars who investigated the marketing aspects in the field of tourism activities should be distinguished the following: N. E. Kudla, O. M. Pravyk, I. M. Shkoda, I. Yu. Martynov and others. The analysis of marketing as a management concept in the tourism services market is carried out in the works of O.M.Azaryan, A. P. Durovich, A. S. Kopanev, V. G. Voronkova, N. L. Zhukova, V. A. Kvartalny, P. Kotler and others.

At the same time, in the works of the majority of authors, the insufficient attention is paid to the study of mechanisms for increasing the efficiency of marketing activities in the field of tourism and managing the demand for a tourist product by means of innovative marketing technologies.

The article is aimed at the development of a structuralfunctional model of the system of marketing approaches to the market for tourism services in Ukraine, the development of a model for managing the process of implementation of certain approaches.

\section{The need to take into account the quality of the tourist product}

Today tourism is one of the dynamic directions of socio-economic development of most countries in the world. In the light of European integration processes, Ukraine is also actively developing in this direction. The clearly expressed need of the society today for meaningful leisure activities requires expanding the range of tourism services. According to O. Lyubovtseva (2005), it is important "to study the proposal as a reflection of the real conditions of the country for the development of the tourism industry." Tourist operators should take into account the demands of the society regarding the quality of the tourist product, the reliability and completeness of information about travel services, means and methods of providing this information, etc.

Specific features of the tourism service provide for its other content, which requires planning and developing new marketing innovative approaches. Intangible nature of the service complicates the decision-making process of a consumer to purchase tourist products, increasing requirements to the level of professional competence of travel agents and tour operators; the separation of the place of sale of tourism services and the place of consumption, which significantly increases the risk of inconsistency of the service received to its expectations; impossibility of accumulation.

This situation is due to insufficient marketing education, ignorance of the leaders of tourism enterprises and staff, as well as insufficient practical experience in this area. In general, $95.7 \%$ of tourist enterprises in Ukraine do not have a marketing department in the organizational structure. However, the fact that it operates is not proof of the priority of a marketing concept. The research confirms that authoritarian methods and reluctance to change outdated management guidelines prevail in the management of Ukrainian tourist enterprises. In other words, the majority of directors of tourist enterprises (100\% of the largest, $96 \%$ of the average, and $95 \%$ of small) are not ready to open access to all information in the enterprise and involve employees to making decisions and forming the marketing policy of the enterprise (Yevtushenko, 2014).

For us, contemporary interpretations of the notion of marketing in tourism, which are considered through the concept of marketing interaction, i.e., when there is the use of communication and social techniques for improving the effectiveness of marketing activities in tourism, are important. We proceeded from the fact that tourism in addition to economic performs a social function, and a travel company should form a socially oriented marketing strategy in the market of tourism services. "The marketing approach to the provision of tourism services suggests that the tourist product is only a 'materialized' means of achieving the purpose of travel. Objects offered in the program of tours, to a certain extent, are a commercial form of tourist product, providing its cost and consumer value" (Pravyk, 2008).

\section{Marketing approaches to providing tourist services}

O. A. Lozova accentuated on marketing in tourism as an activity to stimulate the demand for tourist products (2012). Marketing as a "managed social process" was defined by P. Kotler (2006). It is interesting to define the marketing of tourism services made by N. E. Kudla (2011). The scientist noted that this is: "a complex of measures related to the definition and development of tourist products, as well as its promotion in accordance with the psychological and social factors that need to be taken into account in order to meet the requirements of individuals and groups of people at rest, entertainments by providing them with housing, vehicles, food, leisure facilities, etc." Environmental factors are not directly controlled by travel companies. However, these factors have a very significant impact on customers' behaviour. Therefore, they should always be taken into account not only when making a marketing decision but also in everyday activities. In our view, environmental factors that are constantly to be studied and taken into account in professional activities in the tourism business are presented on a permanent basis in Figure 1. 


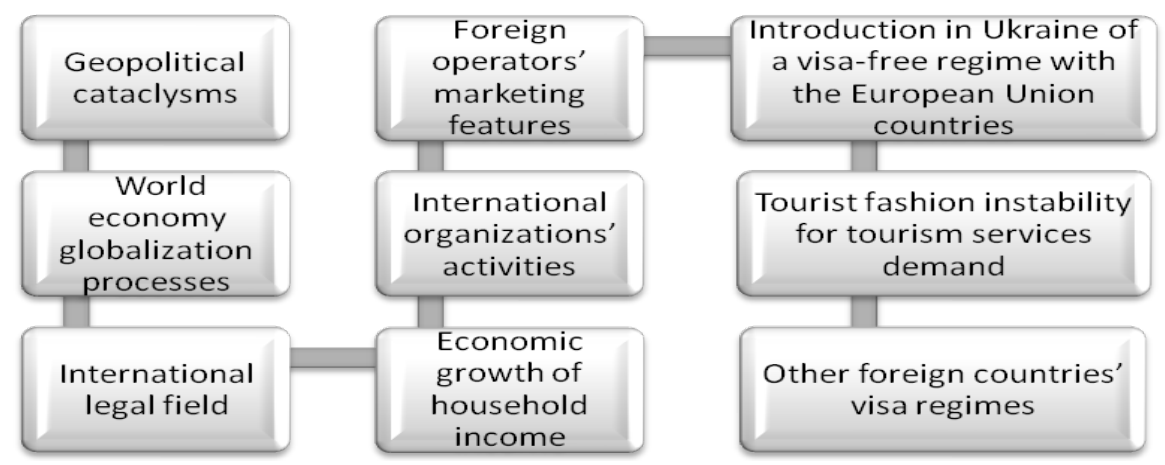

Figure 1. Environmental factors of influencing the tourist enterprises marketing in Ukraine Source: compiled by the authors

Over the past ten years, Ukraine was visited on average by 20 million citizens in 2007, 17.2 million people came to our country (9.7\% less than in 2006), and by 2009 the tourist flow decreased (the impact of the global economic crisis), and from 2010 to 2014 the tourist flow began to increase. So in 2012, taking into account the holding of Euro 2012, our country was visited by 22.4 million people, which is $9.7 \%$ more than in the previous year. After Euro 2012 it became easier for incoming tourism operators to prove potential customers that Ukraine is a very interesting, new, and promising area for tourism, with the corresponding infrastructure, national colour. These facts positively influenced to increasing of tourist flows. About 3.4 million people (the highest number of tourists served by the subjects of tourist activity of Ukraine) fell on the 2013 year, the growth rate of tourists increased by $9.0 \%$ compared with the previous year. In 2014, due to military actions in Donetsk, Luhansk Oblasts, the difficult political situation and temporary occupation of the territory of the Autonomous Republic of Crimea, the tourist flow decreased significantly - by $8 \%$, but starting from 2015, positive trends in its development were determined in the tourism business, the number of tourist arrivals increased on 3\% compared to the crisis 2014 year.

While in the dynamics the number of citizens traveling abroad was not changed significantly during the analysed period, a negative tendency is observed among foreign citizens who visited Ukraine: the largest drop in visits was for 2014-2015 years. In 2016-2017, the number of foreign tourists increased to $7 \%$ in 2016 and $10 \%$ in 2017 years. Thus, there is a steady trend of growth of tourist flows in Ukraine. Such a positive tendency gives an opportunity to talk about the gradual growth of the trust of foreigners to our country.

Ukraine is gradually becoming an increasingly attractive market for tourist services for foreign tourism companies with great potential for its steady development. Ukraine has all the prerequisites for proper economic development through tourism but it loses significantly in the competition, lagging behind the leading countries of the world in terms of the development of tourist infrastructure and the quality of tourist services. According to the components of the tourism competitiveness index in 2017, our state was among the dozens of countries with the lowest level of security and ranked the $127^{\text {th }}$ position, in a favourable business environment - the $124^{\text {th }}$ one, in terms of cultural wealth - the $51^{\text {st }}$, in health and hygiene are not all so bad because it belongs to the top ten countries, ranked the $8^{\text {th }}$, with price competitiveness - the $45^{\text {th }}$, according to tourism service development indicators the $71^{\text {st }}$, with the level of international openness the $78^{\text {th }}$, for the infrastructure of air transport the $79^{\text {th }}$, for land and port infrastructure - the $81^{\text {st }}$, with the focus on tourism - the $90^{\text {th }}$, for natural resources the $115^{\text {th }}$, for human resources and labour market the $41^{\text {st }}$, for ICT readiness - the $81^{\text {st }}$, for cultural resources and business trips - the $51^{\text {st }}$, in terms of environmental sustainability - the $97^{\text {th }}$. In accordance with the general index of tourism competitiveness, Ukraine ranked the $88^{\text {th }}$ position in the ranking of 136 countries (Statystychnyy Ekspres-Vypusk, 2017).

Analysis of comparative dynamics of persons who travelled abroad and those who visited Ukraine during 2007-2017 years, Figure 2 indicates that in the tourist flows in 2012-2013, the ratio was about $49 \%$ to $51 \%$, while in the period of 2014-2017 years, the share of persons traveling abroad was $65 \%$ compared to $35 \%$ of those who visited the country.

One of the important factors in increasing the flow of tourists from Ukraine to Europe is the introduction of a visa-free regime for Ukrainian citizens, first of all, those who used the services of travel companies. After all, far from all Ukrainian citizens have a good command of foreign languages and have the appropriate skills to organize independent travel abroad. At the same time, travel companies are working in a more competitive environment now and, therefore, have to 


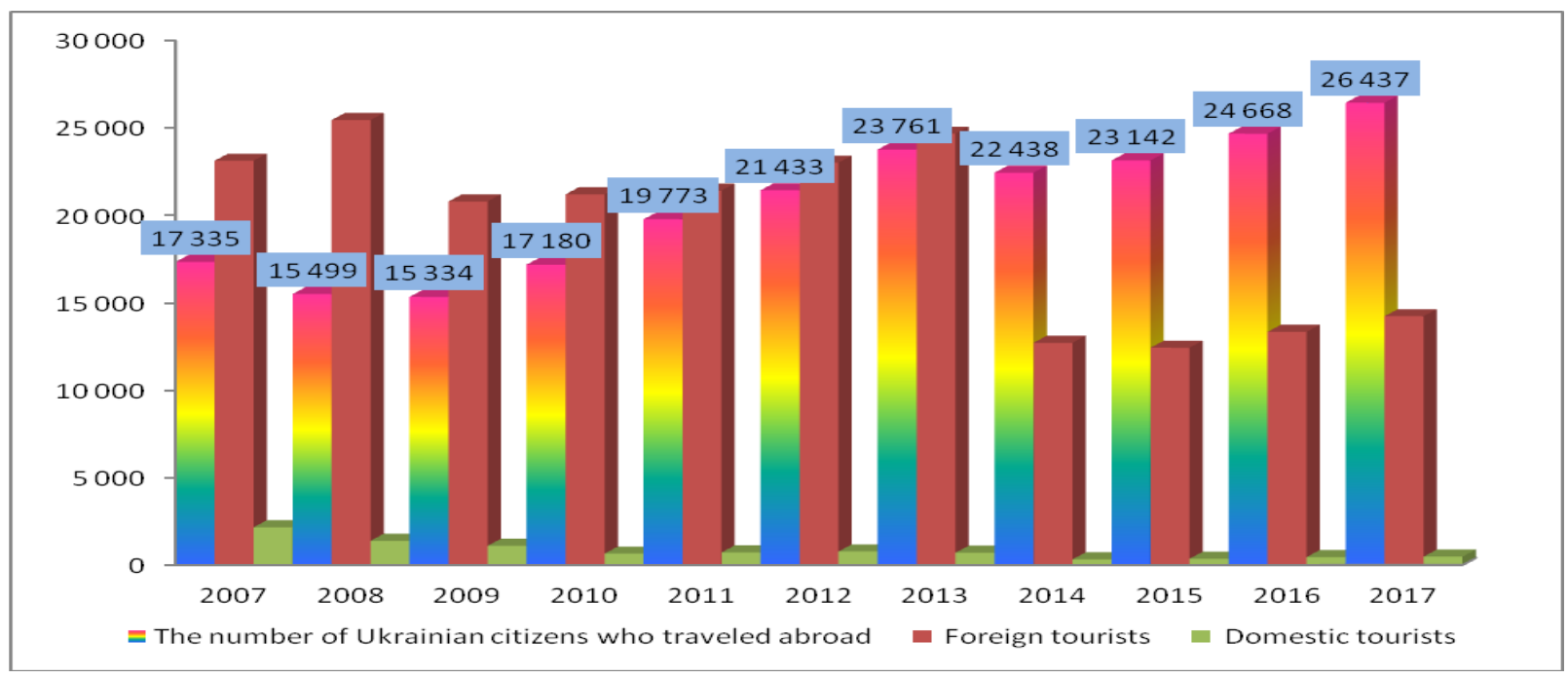

Figure 2. Chart of tourist flows in Ukraine in 2007-2017

Source: compiled by the authors according to countries (Statystychnyy Ekspres-Vypusk, 2017)

not only improve their services (travel) they offer to the Ukrainian population but also look for new tourist routes and interesting channels for the promotion of tourist services. According to the implementation of the strategy for the tourism services market development in Ukraine, the following indicators are expected (Tourism and resorts development strategy until 2026):

1) the increase in tourist expenses during trips to 80 billion UAH in 2026;

2 ) the increase in the volume of capital investment in tourism and resorts to 6.6 billion UAH in 2026;

Such a course of events will stimulate the intensification of competition among Ukrainian travel agencies, encouraging them to diversify their offers. It does not exclude a certain increase in the quality of tourism services and a certain decrease in their prices.

The experience of international tourism development in the Baltic region is rather interesting for Ukraine. For the Baltic countries, such as Estonia, Latvia, and Lithuania - tourism has become one of the most important priorities of economic development. These countries, like Ukraine, are at the crossroads of interregional contacts, the transport routes pass through their territory that allows developing international tourism actively.

According to the forecasts of the World Tourism Organization until 2028, the growth of the tourism sector in the Baltic Sea region will be higher compared to other regions of Europe. The development of tourism will make a significant contribution to economic growth and well-being, Figure 3 (The Economic Impact of Travel \& Tourism, 2018).

Analysis of the comparative dynamics of the contribution of tourism to the GDP of the Baltic States and Ukraine during 2017-2018, Figure 3 indicates that according to the World Travel and Tourism Council (WTTC), the steady growth of tourist flows by 2028 is forecasted (Estonia - 5944.0 million USD, $16.0 \%$ of GDP, Latvia -4385.8 million USD, $10.9 \%$ of GDP, Lithuania - 3371.8 million USD, 6.0\% of GDP, and Ukraine - 7841.4 million USD, $6.6 \%$ of GDP) (The Economic Impact of Travel \& Tourism, 2018).

The positive dynamics of tourism development in the Baltic region of the EU is determined by the structural support of the European Union. Tourism development in Latvia is one of the priority directions in the economy. Thus, in Latvia, there is a steady growth of foreign tourists, and the number of tourists already exceeds 4 million per year, which is almost twice as much as the population of Latvia.

"The tourism development program in the Republic of Lithuania for the years of 2014-2020 uses a slightly modified name - green tourism (ecotourism), which aims to monitor wildlife and local manifestations of culture without negative effect to the environment and providing the local population with socio-economic activities. The purposeful use by Lithuania of the structural support of the European Union has led to the development of local businesses: parks, alleys, cycling trails, beaches, other infrastructure changes that are used not only by tourists from abroad but also by the local population" (Furtie, 2017).

"A fairly fruitful interaction has been organized between the countries of the Baltic States in the development of tourism infrastructure and the provision of electronic services. By common consent, the Scandinavian model was adopted as a basis, which allowed outlining not only actual but also virtual boundaries between countries in the field of transport, travel and hotel business. The development of tourism in the Baltic States accelerated after their accession 


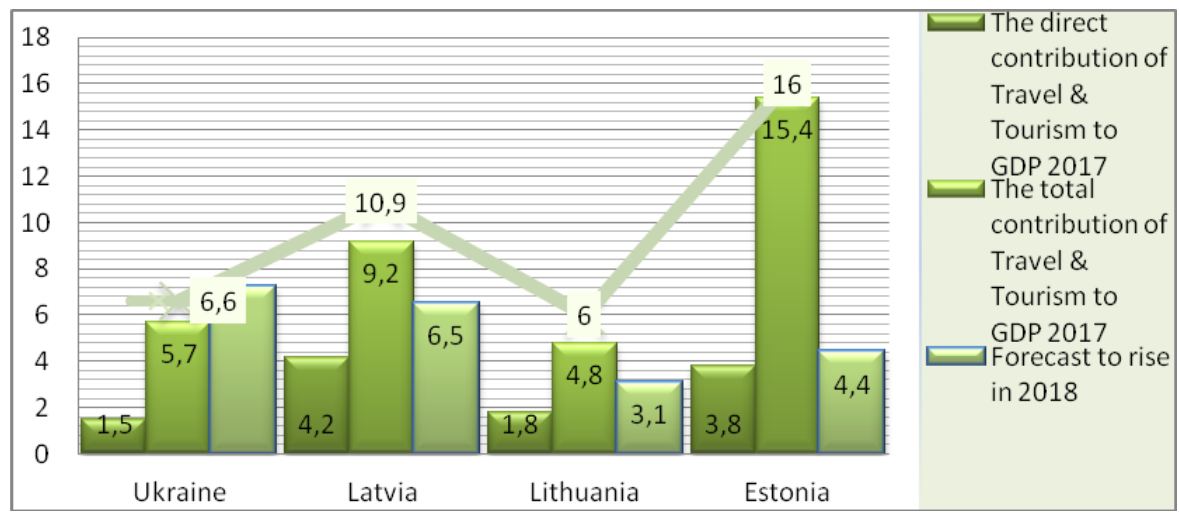

Figure 3. The direct contribution of Travel \& Tourism to GDP in Baltic countries and Ukraine

Source: compiled by the authors according to (The Economic Impact of Travel \& Tourism, 2018)

to the European Union. Thus, all three states are perceived as the only tourist region. They created a single virtual infrastructure for tourist information (websites, brochures, and advertising)" (Furtie, 2017).

The tourism sector of the Baltic countries has their advantages. Firstly, it is the novelty. The Baltic region is still considered quite new and not well-known in the world, which attracts the interest of business travellers. Secondly, it's the geographical availability, which is primarily provided by the airport "Riga". Thirdly, it's the price advantage compared with the countries of Western Europe. Fourthly, there are hotels (especially in the segment of four and five stars), restaurants, and another tourist infrastructure.

The fifth important factor is safety. Following a series of terrorist attacks in Paris and Brussels, traditional destinations for business tourism began to lose their appeal to the organizers of major international meetings. But the demand for small, quiet, and not so popular among tourists of the city, such as Riga, Vilnius or Tallinn, has increased.

The experience of the Baltic Sea Region countries in the EU indicates a more important role of tourism as a powerful factor in the economic growth of GDP, the creation of new jobs, the health promotion of the general population, the development of culture, peaceful contacts between peoples. Tourist activity in Ukraine should become a branch of the specialization of the national and regional economy, an attractive kind of business.

\section{Research methodology}

The current task is to create a complex of positive impressions and feelings of a tourist in order to transform him into a loyal customer with the possibility of applying in the future to him the concept of CEM (Client experience management) (Biletska, 2012).

Establishing effective channels for a communication mechanism for providing information and creating a positive image of tourism services requires a reassessment of the importance and role of marketing and its tools. The study of the problem suggests that marketing aspects of the tourism industry require the development of more "effective tools, a single management space, which can ensure the integrity of the management system of the market, the effectiveness of the relationship of its components, coordination and interconnection of tourism subjects" (Gorina, 2016).

It is important to study tourism as an integrated system that includes various subsystems: financial and credit, medical, transport, cultural and entertainment, health and recreational, informational and advertising, etc. The system approach in tourism gives an opportunity to come to the study of this social phenomenon from a philosophical, sociological, and psychological point of view. The analysis of the market for tourism services with the use of a systematic approach has allowed us to distinguish its structure, and also to substantiate a set of indicators of evaluation of its results.

The system approach allows us to take into account the variability of individual parameters of the system of marketing approaches to the market for tourism services, especially its behaviour in specific conditions, its uniqueness and unpredictability, the ability to adapt to changing conditions. An important feature of the system is its ability and desire for goal-formation, that is, the formation of goals within the system.

Let us note that the demand for a tourist product is unbalanced, prone to seasonal fluctuations, depends on many other factors, in particular, the geographic location of the region, political relations, socio-demographic, etc.

It is important to create a structural and functional model of a system of marketing approaches to the market of tourism services, the elements of which will interact with each other and will be aimed at informing the consumer about the range of services, establishing a communication mechanism for providing information, creating a positive image for a particular tourism service. In this context, the problem of the development of 
channels and communication tools, the possibility of access to a range of sources on services for the use of innovative marketing technologies is actualized.

The structural-functional model of the system developed by us is a multilevel structure, which consists of factors, marketing methods and techniques, forms of realization of the tourist product, Figure 3 . The mechanism of the formation of demand for tourist services by means of marketing technologies is determined by the peculiarities of consumption of tourism services, implementation of certain factors (nature of consumption, stimulation of demand, and promotion of tourism services, etc.), determined by the marketing methods and techniques, in the first place, innovative, Figure 4.

Modelling, developing, and implementing models are powerful mechanisms for determining and achieving a new qualitative tourism services market. Modelling as a methodological principle and a method of scientific knowledge allows, through the perfect creation of the

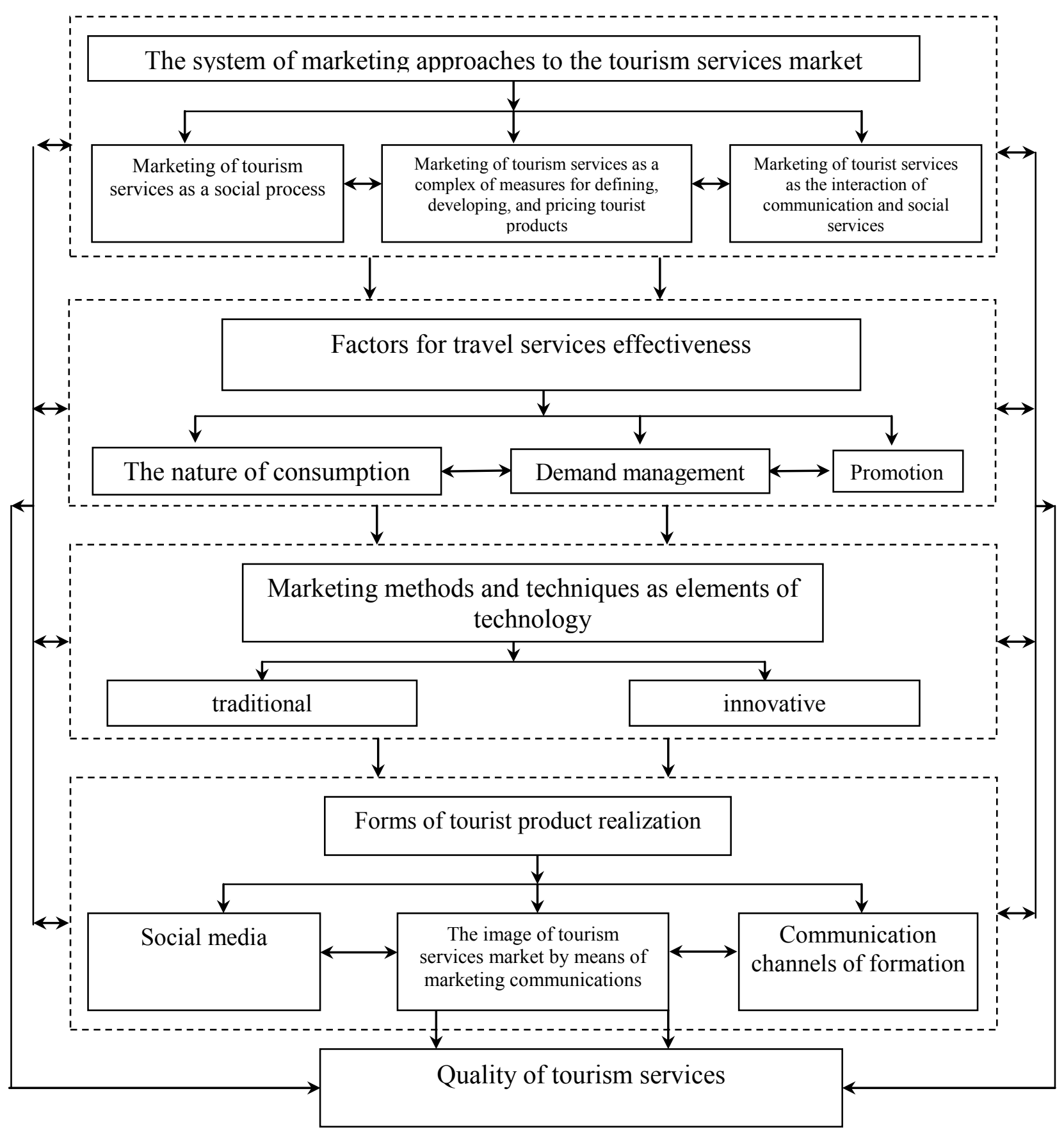

Figure 4. Structural-functional model of the system of marketing approaches to the tourism services market Source: compiled by the authors 
system, its structure to determine the directions of management activity for the adoption of an adequate solution. It has been shown that the condition of the successful functioning of the named system is the integration of certain components that provide the qualitative characteristics and properties inherent in this system. Among the characteristics of complex systems, in particular, the system of marketing approaches to the market for tourism services, one of the most important is the necessity to manage it.

This process is carried out indirectly due to our organizational model of operational management of the

The mechanism of formation and management of tourist product demand by means of innovative marketing technologies

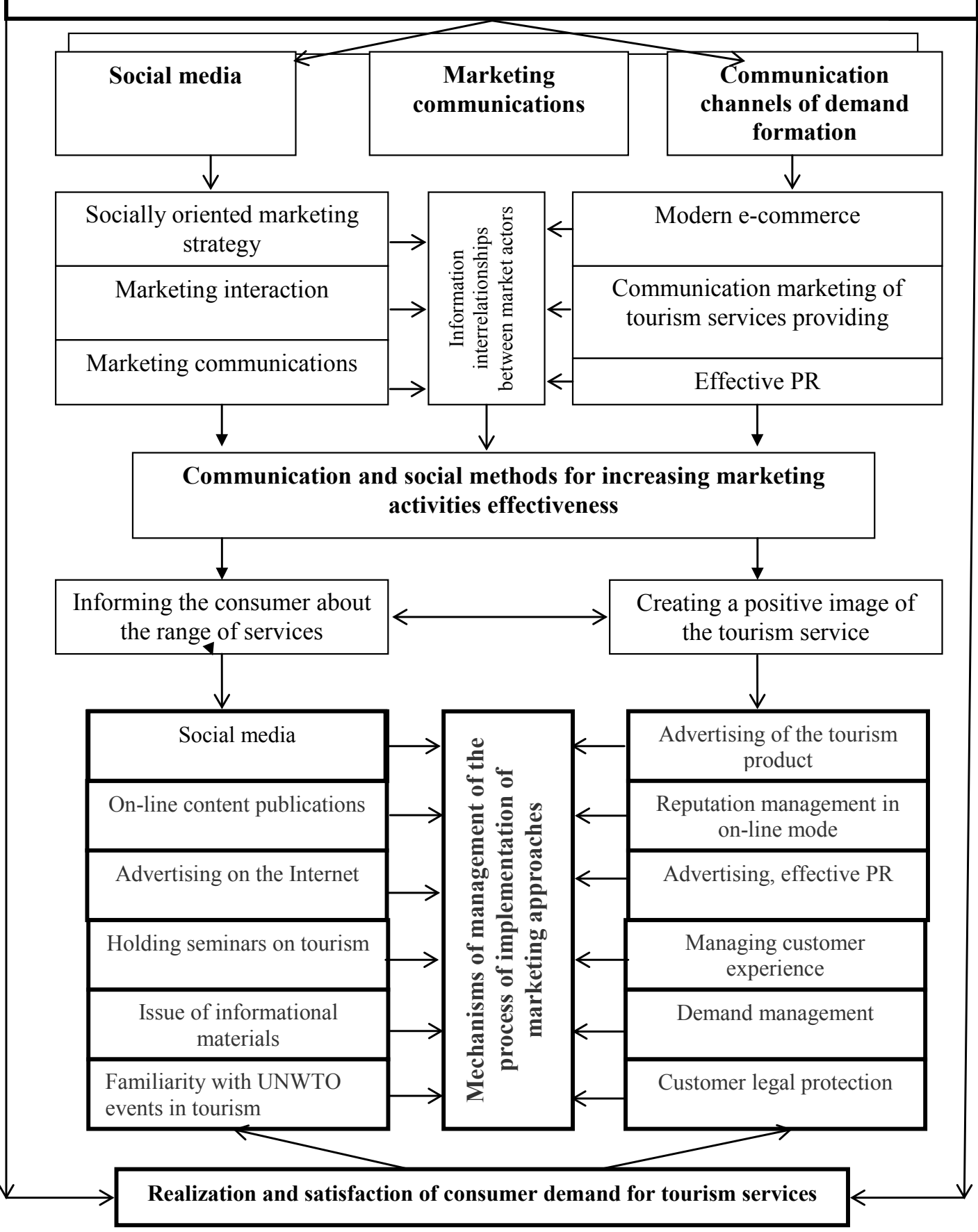

Figure 5. Model of the implementation process management of marketing approaches to the tourism services market

Source: compiled by the authors 
process of implementation of marketing approaches to the market for tourism services.

The use of such a model allowed decentralizing the control effect on the process of effective implementation of tourism services, demand management, pricing, and promotion. We have identified effective mechanisms for the formation and management of demand for a tourist product: social media, marketing communications and communication channels for the formation of demand. They form the image of the tourism services market on the basis of establishing information relationships between market players (consumers, sellers, intermediaries). The components of the management model are also defined by communication and social methods of improving the effectiveness of marketing activities, which are inextricably linked with the main marketing objectives of the tourist enterprise: customer service satisfaction, increased number of loyal customers, increased profitability, etc. It is important to pay more attention to modern innovation-communication marketing technologies, which form the model of interaction of subjects in the market for tourism services. In particular, a significant role in creating a model of proficient service belongs to different forms of social media marketing (online content publishing, advertising on the Internet, social bookmarking services, etc.).

It is necessary to take into account the uniqueness of social media, namely the possibility of their interaction directly with the consumers of services. And also the fact (according to Worldometers) that the number of people having access to the Internet is growing rapidly, and in 2019 it could reach 7.6 billion people. In particular, 1.9 billion people are actively using social networks. More than $40 \%$ of the world's population is currently connected to the Internet, and by the end of 2017, about 2.9 billion users are forecast (Teletov, 2010). All this requires not only a revision of obsolete approaches but also the construction of new modern marketing strategies for the development of the tourism market. One of the effective mechanisms for managing the process of implementing marketing approaches is the interest of consumers, the conquest of consumer attention by creating a positive image of the tourism service. We are talking about product promotion, effective advertising, consumers' experience, and demand management. It is important to coordinate the actions, optimize management decisions that will improve the quality of the tourism services provided.

\section{Conclusions}

Implementation of marketing approaches to the market for tourism services involves a socially oriented marketing strategy based on social and psychological factors promoting the tourist product. The mechanisms of influence on the formation and management of demand developed by us provide for a systematic approach to the market for tourist services.

The structural and functional model of a marketing system approach takes into account factors of the efficiency of tourism services, marketing methods and techniques, as well as forms of realization of tourist product that provide the quality of tourism services.

We have determined that the effectiveness of the functioning of the system of marketing approaches depends on the creation of a coherent management space in terms of the integration of its components. In the process of developing tools for implementing the components of a marketing system, we have identified the most effective management method. The model of managing the process of implementing marketing approaches to the market for tourism services developed by us will allow us to decentralize the managerial influence on demand, pricing, and promotion of the tourist product.

\section{References:}

Biletska, I. M. (2012). Osoblyvosti marketynhu turystychnykh posluh v suchasnykh umovakh hlobalizatsii svitovoho turystychnoho rynku [Peculiarities of marketing of tourism services in the modern conditions of globalization of the world tourism market]. Economy of Crimea, 441, 389-397.

Gorina, G. O. (2016). Rynok turystychnykh posluh: upravlinnia rozvytkom v umovakh prostorovoi poliaryzatsii: monohrafiia [Market of tourism services: development management in the conditions of spatial polarization: monograph]. Kryvyi Rih: Chernyavsky D. O. (in Ukrainian)

Derzhkomstat Ukrainy: turystychni potoky, 2017 [State Statistics Committee of Ukraine: Tourist flows, 2017]. Retrieved from: http://www.ukrstat.gov.ua/operativ/menu/menu_u/tur.htm (accessed 2 January 2018)

Zayachkovska, G. A. (2010). Evoliutsiia teorii marketynhu turyzmu [Evolution of the theory of tourism marketing]. History of the national economy and economic thought in Ukraine, 43, 193-201.

Yevtushenko, O. V. (2014). Zastosuvannia kompleksu marketynhu v sferi turyzmu [Application of marketing complex in the field of tourism]. Vestnik KhNU named after V. N. Karazin, 1144, 166-170.

Kudla, N. E. (2011). Marketynh turystychnykh posluh [Marketing of travel services]. Kyiv: Znannya. (in Ukrainian) Lozova, O. A. (2012). Turyzm v Ukraini: suchasnyi stan, problemy ta perspektyvy rozvytku [Tourism in Ukraine: the current state, problems and prospects of development]. Cultures of the peoples of the Black Sea region, 229, 44-47.

Kotler, P., Keller, K. L. (2006). Marketynh-menedzhment [Marketing-Management]. St. Petersburg: Peter. (in Russian) 
Kulytsky, S. (2017). Imovirni ekonomichni naslidky vid zaprovadzhennia bezvizovoho rezhymu Yevropeiskoho Soiuzu dlia Ukrainy [Probable economic consequences of the introduction of a visa-free regime of the European Union for Ukraine]. Ukraine: events, facts, comments, 12, 52-64. Retrieved from: http://nbuviap.gov.ua/images/ ukraine/2017/ukr12.pdf (accessed 10 January 2018)

Stratehiia rozvytku turyzmu ta kurortiv na period do $2026 \mathrm{r}$. [Tourism and resorts development strategy until 2026]. Retrieved from: http://zakon2.rada.gov.ua/laws/show/168-2017 (accessed 8 January 2018)

Lyubivtseva, O. O. (2005). Rynok turystychnykh posluh (heoprostorovi aspekty) [Market of tourism services (geospatial aspects)]. Kyiv: Altpress. (in Ukrainian)

Pravyk, Yu. M. (2008). Marketynh turyzmu: pidruchnyk [Tourism marketing: Textbook]. Kyiv: Znannya. (in Ukrainian)

Teletov, A. C. (2010). Marketynhovi doslidzhennia: navch. posib. [Marketing research: tutor. manual.]. Kyiv: Znannya. (in Ukrainian)

Fedorchenko, V. K., Nichkalo, N. G. (2004). Teoretychni ta metodychni zasady pidhotovky fakhivtsiv dlia sfery turyzmu: monohrafiia [Theoretical and methodological principles of preparation of specialists for the sphere of tourism: monograph]. Kyiv: Publishing House "Slovo". (in Ukrainian)

The Economic Impact of Travel \& Tourism 2018. European Union. Retrieved from: https://www.wttc.org/ economic-impact/country-analysis/country-reports/\#undefined (accessed 20 September 2018)

Statystychnyy Ekspres-Vypusk (2017). [Statistical Express-Discount, 2017]. Retrieved from: http://www.ukrstat.gov.ua (accessed 20 September 2018)

Furtij, V., Korsak, R. (2017). Istorija rozvytku turyzmu u krajinax Baltyky (Estonija, Latvija, Lytva) [The history of tourism in the Baltics (Estonia, Latvia, Lithuania)]. "Gilea: Scientific Bulletin": Collection of scientific works, 118, 156-163. 